Chapman University

Chapman University Digital Commons

Education Faculty Articles and Research

College of Educational Studies

$11-14-2014$

\title{
"Just as Bad as Prisons": The Challenge of Dismantling the School-to-Prison Pipeline Through Teacher and Community Education
}

Quaylan Allen

ChapmanUniversity, qallen@chapman.edu

Kimberly A. White-Smith

Chapman University, kwsmith@chapman.edu

Follow this and additional works at: http://digitalcommons.chapman.edu/education_articles

Part of the African American Studies Commons, Curriculum and Social Inquiry Commons, Higher Education Administration Commons, Race and Ethnicity Commons, and the Social and Philosophical Foundations of Education Commons

\section{Recommended Citation}

Allen, Q. and K. A. White-Smith. (2014). Just as Bad as Prisons: The Challenge of Dismantling the School-to-Prison Pipeline Through Teacher and Community Education. Equity \& Excellence in Education, 47(4), 445-460. DOI: 10.1080/ 10665684.2014.958961 accepted for inclusion in Education Faculty Articles and Research by an authorized administrator of Chapman University Digital Commons. For more information, please contact laughtin@chapman.edu. 


\section{"Just as Bad as Prisons": The Challenge of Dismantling the School-to- Prison Pipeline Through Teacher and Community Education}

\section{Comments}

This is an Accepted Manuscript of an article published in Equity \& Excellence in Education, volume 47, issue 4, in 2014, available online: DOI: 10.1080/10665684.2014.958961.

\section{Copyright}

Taylor \& Francis 
"Just as bad as prisons": The challenge of dismantling the school-to-prison pipeline through teacher and community education

\author{
Abstract \\ Drawing upon the authors' experiences working in schools as teachers, teacher educators, \\ researchers, and community members, this study utilizes a critical race theory of \\ education in examining the school-to-prison pipeline for Black male students. In doing \\ so, the authors highlight the particular role educators play in the school-to-prison \\ pipeline, focusing particularly on how dispositions toward Black males influence \\ educator practices. Recommendations and future directions are provided on how \\ education preparation programs can play a critical role in the transformation of Black \\ male schooling.
}




\section{"Just as bad as prisons": The challenge of dismantling the school-to-prison pipeline through teacher and community education}

A significant body of literature on the life outcomes of Black males examines how school practices and policies file children out of educational environments and into the criminal justice system (Aud, Fox, \& Kewal Ramani, 2010; Gregory, Skiba, \& Noguera, 2010; Harry \& Klingner, 2006; Losen \& Martinez, 2013; Nicholson-Crotty, Birchmeier, \& Valentine, 2009). Indeed, many urban schools have transformed from places of learning and hope to holding cells adorned with metal detectors and heavy police presence (Price, 2009; Reaves, 2011). The impetus of this paper partly stems from personal communication between one of the researchers and her brother. The researcher was attempting to assist her sibling in picking a school for her nephew, a young Black male. Her brother exclaimed, "If you want to make it in this world you need education. He don't want to go to these regular public schools in Compton, they just as bad as prisons." (Personal Communication, November 7, 2011)

This quote captures the unspoken pressure and responsibility that Black parents feel to protect their children, especially their sons, from the negative consequences of urban schooling and the "school-to-prison pipeline. Correlative with the opinion of the father in the quote, there is evidence to support the connection between the punitive practices and restrictive culture of the public school system and the prison system, which focuses on criminalization rather than education and rehabilitation (Nicholson-Crotty, Birchmeier, \& Valentine, 2009; Swain \& Noblit, 2011). In fact, $3^{\text {rd }}$ and $4^{\text {th }}$ grade reading test score data, and high-school dropout rates are often used to predict space needs for 
state prisons (Bonstingl, 2002; Giroux, 2009). Many Black parents feel terror and dread that this system of institutionalized bigotry and racial oppression will crush their sons (Beard \& Brown, 2008).

This article derives from the authors' combined years of experience working in schools in various roles: as family members, teachers, teacher educators, researchers, community members, and activists in the struggle to dismantle the school to prison pipeline. The question "What can be done to disrupt the school-to-prison pipeline?" is multifaceted and complex. In this article, we present counter-stories to offer alternative ways to examine the school to prison pipeline and to present our work as teacher educators to enrich the discussion on the school to prison pipeline. .

\section{Critical Race Theory of Education and the School-to-Prison Pipeline for Black males}

School policies and practices often play a significant role in the systemic failure of Black males and their consequential placement in the school-to-prison pipeline. As elements of a stratifying institution, policy decisions and teacher practices reproduce economic and racial inequalities for many in poverty and people of color, specifically Black males (Aud, Fox, \& Kewal Ramani, 2010; Cooper, 2003; Gregory \& Weinstein, 2008; Losen \& Martinez, 2013; Oakes, 2005). For this reason, Critical Race Theory (CRT) is particularly useful as an analytical tool to examine structural barriers that Black males face in school. As a critical theory (Horkheimer, 1972), with roots in legal studies (Bell, 1992; Crenshaw, Gotanda, Peller, \& Thomas, 1995), CRT centers on race and its intersection with other identities (i.e. gender) in the examination of social and 
institutional subordination of marginalized groups (Delgado \& Stefancic, 2001; LadsonBillings \& Tate IV, 1995; Matsuda, Lawrence III, Delgado, \& Crenshaw, 1993).

Pertaining to education, Solórzano (1998) describes CRT as a theory that "challenges the dominant discourse on race and racism as they relate to education by examining how educational theory, policy, and practice are used to subordinate certain racial and ethnic groups" (p. 122). The literature on CRT generally points to five major tenants of the theory which include: a) the importance of placing race and its intersection with other identities, at the center of critical examination, b) challenging dominant ideology and majoritarian narratives that claim to be universal, neutral, and colorblind, c) centralizing the experiential knowledge of marginalized groups through counterstorytelling or personal counternarratives, d) a commitment to social justice, and e) an interdisciplinary use of the theory as an analytic and methodological tool. Thus, CRT makes clear how race and gender intersect for Black males in how they encounter various school structures (Bell, 1992; Crenshaw, 1993; Delgado, 1991; Dixson \& Rousseau, 2006; Ladson-Billings \& Tate IV, 1995; Daniel G. Solorzano \& Bernal, 2001; Yosso, 2006)

For instance, when examining school policies and Black male achievement, a critical race theory of education exposes how Black boys are disproportionally likely to attend inequitably funded public schools, have unequal access to school knowledge, and are thus likely to be sorted into lower ability academic tracks (Anyon, 1981; Bowles \& Gintis, 2002; Oakes, 2005). Though legalized racial segregation in schools is unlawful, de facto school segregation as a result of residential segregation (e.g. by race and class) allows school systems to act as colorblind institutions while maintaining racial 
inequalities through vastly under-resourced schools (Dixson \& Rousseau, 2006; LadsonBillings \& Tate IV, 1995; Orfield \& Lee, 2007b). In this way, the current state of racial and class school segregation indirectly contributes to the school-to-prison pipeline for Black men in that poor educational opportunities contribute to high unemployment rates and poverty, making Black males more susceptible to encounters with the criminal justice system (Hoffman, Llagas, \& Snyder, 2003; Oliver \& Shapiro, 2010; Pettit \& Western, 2004; Sampson, 1987; Sum, Khatiwada, \& McLaughlin, 2009; U.S. Department of Labor, 2013).

In addition to these macro-structural factors, individual educators also play a critical role in the systemic failure of Black males. The path towards social mobility is often dependent on what educators, as academic gatekeepers, do or don't do in their schools. To a large degree, the development of these gatekeepers begins in education preparation programs. These programs which prepare teachers, counselors, and administrators are currently comprised largely of White middle-class women from suburban upbringings (Coopersmith, 2009; Tab, 2007). This means that though the nationwide population of school children has become increasingly diverse, the educators working in these schools are largely a homogeneous group. Considering that schools have become increasingly segregated as a result of failed or reversed desegregation policies (Mickelson, 2001; Orfield \& Lee, 2007a), it is likely that these prospective educators have had little meaningful cross-cultural interactions prior to entering the university (Causey, Thomas, \& J. Armento, 2000; Wiggins, Follo, \& Eberly, 2007), yet they will act as gatekeepers for an increasingly culturally diverse student population. 
Education programs are thus locations in which future educators can acquire the competencies needed to meet the needs of a diverse student population. While many teacher and counselor preparation programs require coursework and field experiences that address diversity, critical self-reflection, and cultural relevant practices, it is not clear if and how these opportunities effectively prepare teachers for work in diverse schools (Council, 2009; Holcomb-McCoy \& Day-Vines, 2004; Milner IV, 2005). Furthermore, it is unclear if these opportunities help White educators understand their own role in the maintenance or disruption of school-to-prison pipeline processes. For example, in teacher preparation programs, teacher candidates may resist or show indifference to the discussion and analysis of racial issues, choosing instead to adopt colorblind approaches to viewing their students (hooks, 1995; Ladson-Billings, 1996; Milner IV, 2008), a position that according to CRT, simply camouflages the self-interests of dominant groups and maintains that status quo of inequalities. In adopting these colorblind approaches, White teacher candidates not only exonerate themselves in the maintenance of racial hegemony, but also miss out on understanding how social and institutional racism pervade the lived experiences of students of color.

The avoidance of examining the racialized "other" means that many educators rely on their own understandings of students of color, which in many cases reflect majoritarian deficit views of culture (Constantine \& Gushue, 2003; Delpit, 1995; Daniel G. Solorzano, 1997; Watson, 2011). In other words, because of the lack of cultural congruence and familiarity White educators have with their students of color, they often rely on dominant but inaccurate, stereotypical and negative assumptions about the ability of their students. Deficit approaches tend to blame the victim for his social woes and 
assume the student is intellectually inferior or educationally indifferent, without considering how structural impediments, such as racism, influence educational opportunity and, thus, academic outcomes. Indeed, many teacher candidates view students from low-income communities through these deficit lenses and when coursework and fieldwork experiences fail to critically examine race and class, these experiences risk reinforcing deficit views as opposed to challenging them (Melnick \& Zeichner, 1995; Vavrus, 2002).

When teacher candidates and other educators finally enter into the professional ranks, their cultural and racial incongruences and deficit views of students of color converge with existing school policies and practices in ways that contribute to the schoolto-prison pipeline. For example, as a result of racial incongruence and the overreliance on dominant discourse regarding Black males, teachers regularly perceive their Black male students as deviant and interpret Black male behaviors as overly aggressive, disrespectful, defiant, and intimidating even when the intent of these behaviors was just the opposite (Davis, 2003; A. Ferguson, 2000; Monroe, 2005). Black males are then subject to much more surveillance than their classmates as teachers grapple with their own fear of losing classroom control (Fenning \& Rose, 2007; Raible \& Irizarry, 2010). The heightened surveillance and misinterpretation of Black male behaviors play a critical role in Black males experiencing discipline that is unnecessary, and in many cases, harsher for them than it would be for their White counterparts (Monroe, 2005; Skiba, 2001).

For both young Black men and their parents, the realization of this type of differential treatment is a source of frustration and greatly impacts both the quality of 
their educational experience and also the academic trajectories they can ultimately take (Allen, 2013; Howard \& Reynolds, 2008). The intersection of teacher biases, misinterpretations of Black male behaviors, and disciplinary policies (e.g. zero tolerance), contribute to the overrepresentation of Black males in school suspensions and expulsions (Aud, Fox, \& Kewal Ramani, 2010; Gregory, Skiba, \& Noguera, 2010; Losen, 2011; Swain \& Noblit, 2011; Wald \& Losen, 2003). Furthermore, Black boys attending schools with increased police presence on campus are much more vulnerable to punitive actions that place them directly under police custody, and into the school-to-prison pipeline (Guerino, Harrison, \& Sabol, 2011; Nolan \& Willis, 2011).

In a similar fashion, the fear and intimidation many teachers and administrators use to justify excessive discipline also produces similar racist and deficit views about Black male intelligence and academic capability. Teacher and school counselor bias frequently manifests itself in low expectations of Black male students as well as assumptions of academic indifference (R. Ferguson, 2005; Lynn, Bacon, Totten, Bridges, \& Jennings, 2010; van den Bergh, Denessen, Hornstra, Voeten, \& Holland, 2010). Such views are identified as contributing to the misclassification of Black males as students with disabilities, leading to the overrepresentation of Black males in special education or remedial programs. (National Research Council, 2002; Ford, 1998; Grantham, 2004a; Harry \& Klingner, 2006; Vincent, Rollock, Ball, \& Gillborn, 2012). This form of racebased tracking limits the educational and subsequent occupational opportunities of Black males, increasing the likelihood that undereducated and underemployed Black men enter into the judicial system (Sum, Khatiwada, \& McLaughlin, 2009). Thus, a critical race theory of education makes clear how racial incongruence, teacher bias, colorblind school 
discipline policies and racialized tracking intersect in ways that deny Black males meaningful learning opportunities, limits their occupational outlooks, and disciplines them in ways that directly (campus arrests) or indirectly (poor work preparation) places them in the school-to-prison pipeline.

Finally, in addition to examining how school policies and practices subordinate certain racial groups, a critical race theory of education aims to challenge dominant ideologies and majoritarian narratives by centralizing the experiential knowledge of marginalized groups. This is achieved through counter-story telling methodologies, an important tool within CRT that examines the personal narratives from members of marginalized groups that may counter dominant and majoritarian accounts of events (Delgado, 1995; Fernandez, 2002; Harper \& Davis III, 2012; Yosso, 2006). Solorzano and Yosso (2009) define counter-story as:

a method of telling the stories of those people whose experiences are not often told (i.e., those on the margins of society). The counter-story is also a tool for exposing, analyzing, and challenging majoritarian stories of racial privilege. Counter-stories can shatter complacency, challenge the dominant discourse on race, and further the struggle for racial reform. (p. 138)

In this article, we present a collection of counter-stories drawn from our work as educators and researchers that elucidate implications of race and gender for Black male students. In particular, the counter-stories come from the research studies we've conducted on Black male schooling, as well as personal stories from our own practices as teachers and teacher-educators of color. These counter-stories are analyzed using critical race theory and within the context of the existing literature on Black male schooling. 


\section{Concrete and steel: How pipeline construction is initiated in schools}

As conscious educators working in K-12 schools, we find systemic marginalization of Black bodies so pervasive that it takes little effort to identify instances where educators participate in the school-to-prison pipeline. This type of marginalization is engrained within school culture to the extent that it is normalized. That educators adopt normative deficit views of their Black boys by assuming deviance, low intelligence, and holding low expectations is itself a systemic problem we seek to address. In this section we present and examine a collection of counter-stories describing how educators draw upon normative assumptions of Black males and act in ways that greatly influence the academic and social trajectories of their students. Although we begin our focus on teachers, it is also understood that as a systemic problem, counselors and school administrators play a profound role in student academic success or failure (Leathwood \& Jantzi, 2000; White-Smith, 2012b; White-Smith \& White, 2009). Ultimately, the recommendations we will provide address how education preparation programs can serve as a site of systemic transformation for all that enter the profession.

Teachers. There are many factors that influence student academic outcomes, including the home environment, access to resources, student self-efficacy, and peer influences. However, the most powerful and persistent element affecting student academic outcomes is the teacher (Darling-Hammond, 1999).

The following narrative, a personal experience of one author, illustrates the connection between teacher perspectives and resultant impact:

I was hired at a school as a full-day kindergarten teacher. The school demographic was predominantly White, though to increase its student 
diversity the school voluntarily participated in a bussing program with the surrounding local communities. Although I self-identify as Black, having one biological White parent affords me the privilege and burden that comes from phenotypically appearing racially ambiguous to others. At times I am included in conversations that I would not otherwise, if I 'looked Black.' On Monday of the second week of school, I was invited to have lunch with two other kindergarten teachers, Ginny and Karen, both White. As the conversation waned, Ginny spoke up, 'I have Annika in my class!' Annika was a new student not just to our school, but also to the country. She and her family moved to the U.S. from Switzerland and all the teachers were taken with the child's beauty when she and her parents came to register. Ginny continued [holding her hands to her face to give an angelic appearance], 'She really is amazingly beautiful. She has the most incredibly blonde hair I have ever seen and the deepest blue eyes.' Karen responded, 'You are so lucky. I wanted her in my class. I hope the other kids are being welcoming to her and treating her well.' Ginny replied, 'Oh yes. A little too well.' Ginny stood up and puffed out her chest, broadening her shoulders and making a motion with her legs as if she were walking. She stated, 'Yesterday, Craig, this BIG AFRICAN AMERICAN BOY, walks up to her and as says [using a deep, gruff voice], 'Can I play with you'? I couldn't believe it. Why would he think he had the right to touch her?' Karen asked, 'So what did you do?' Ginny responded, 'What any normal human being would do, I sat him in a corner until he learned 
some respect.' Karen turned to me, her face seething in disgust, and asked, 'Can you believe that?' I looked at her. I could feel the heat rising to my face. The anger and outrage was almost too much to contain. I whispered, 'He is 5 years old. He is a little boy.' I stood up and mimicked Ginny's movements as she mocked the young man and stated in a big voice so other teachers could hear, 'I don't have a problem with BIG AFRICAN AMERICAN BOYS being friends with beautiful LITTLE WHITE GIRLS; otherwise I would not be here.' I left the table and the two teachers behind so they could think about and discuss what I had just told them. I walked directly to the principal's office and asked for Craig to be transferred to my classroom. I explained why and the principal took care of it that day.

The teachers' assumption of the author's whiteness is evidence of both the social construction of race and how whiteness as a conferred privilege becomes a property function (Harris, 1993). By this we mean that when the teachers assumed the author was white, they conferred upon her the privilege that comes with whiteness, including the property rights of disposition, reputation and the absolute right to exclude (Ladson-Billings \& Tate IV, 1995). In other words, as a perceived white person within this particular social interaction, the author's disposition was normalized as appropriately "white", was assumed reputable enough to engage in such a discourse laden with power, and was afforded the right to engage in an exclusionary discourse about Black boys.

Secondly, within this social interaction is evidence of the discursive 
practices regarding Black male ontology. Craig, the Black male student is constructed in relation to Annika, a female from Switzerland who has become white since arriving to the U.S. (Barrett \& Roediger, 2003). While Annika is described through a discourse of white female innocence, Craig is described as a nuisance and threat to Annika's supposed purity. In describing both Craig and Annika in these particular ways, the teachers draw upon a deeply historical ontological reasoning of Black male deviancy and racial inferiority (Fanon, 1967; hooks, 2003; Yancy, 2005), where even Black boys in kindergarten are hypersexualized and considered a threat to white female sexuality.

Finally, the early childhood years (preschool through third grade), are a critical time in the developmental trajectory of children. Factors that impact Black boys' status in early childhood settings include teacher beliefs, expectations, and behaviors (Rashid, 2009). There is evidence that teacher ideologies, particularly the criminalization of Black boys, contribute to how Black boys are disciplined, surveilled on campus and afforded equitable learning opportunities (Aud, Fox, \& Kewal Ramani, 2010; Gregory, Skiba, \& Noguera, 2010; Losen, 2011; Swain \& Noblit, 2011; Wald \& Losen, 2003). In the presented counter-story, the teachers criminalized behavior that is typical and positive for a kindergartener; Craig was proactively making friends, welcoming a new student, and politely asking to play. However, the teachers attempted to extinguish this behavior by using the exclusionary practice of in-class punishment.

The attitudes of these particular teachers seem to not only contribute to how Black masculinities are constructed and policed in school, but also point to 
how teacher ideologies shape how they talk and interact with their Black male students (R. Ferguson, 2005; Gregory, Skiba, \& Noguera, 2010; Lynn, et al., 2010). The persistent disproportionate use of exclusionary discipline by teachers contributes to the systemic failure of Black boys, and further exposes them to similar discipline within the juvenile justice system (Nicholson-Crotty, Birchmeier \& Valentine, 2009).

Counselors. Like teachers, counselors and school administrators also play implicit but vital roles in the systemic failure of Black males (White-Smith, 2009). For example, at a racially diverse high school in which one author was observing (Allen, 2010a), there had been a recent overhaul of the school counseling department. For years, Black parents had accused school counselors of contributing to a racialized academic tracking system where Black students regularly found themselves in lower ability or special education programs. Both students and parents at the school shared stories of apathetic counselors who drew upon deficit approaches to determine the academic capabilities of students of color.

In response to these accusations, the school administration hired counselors who had multicultural counseling competence and were better prepared to work with culturally diverse populations. Some of these counselors were people of color themselves. A mother shared her relief with the author regarding the new hires, recounting a situation with her own son, a high achieving student. She explained her son inquired of his previous counselor about enrolling in a foreign language course, to which the counselor responded that the course might be too hard and should not be taken. Instead, the counselor suggested a vocational track course that would not have counted 
toward any of the statewide university requirements as the foreign language course would. This outraged the mother, who demanded of the vice principal and counselor that her son be enrolled in the desired class, in part precipitating the change of school counselors.

This scenario is also consistent with the experience of another Black family participating in an earlier study of Black male students attending secondary schools (Allen, 2010b). Lynette, a lower-middle-class single mother of three children shares a similar frustration with school counselors as she describes the outcome of a career counseling session her son Andrew, student with a 3.0/4.0 grade point average, had with his school counselor.

... he came home and I was so excited because I thought, 'Great! They're going to have it all mapped out'...she [the counselor] says 'You know, there's a lot of 4.0 students, there's none of [those scholarships] available to you right now. Your grades aren't that high, but if you want to think of a community college, if you want to play football, that would be okay for you, but let me get you some brochures.' And she handed him the technical brochures for technical places. Like automotive school!? [laughs] And there is nothing wrong with that if Andrew excelled at it. But to not even say there is a road for you to follow. You need to reach your highest potential or to even offer that opportunity? I heard him talk and I was stunned. And I was livid (p. 133).

Both of these situations point to specific moments where Black males are excluded from educational opportunities, despite their previous academic achievements. The examples also highlight the way school counselors in secondary education often intentionally or 
unintentionally act as gatekeepers to their students (Banks, 1978; Erickson, 1975). Like teachers, counselors are able to create moments of either inclusion or exclusion (Lareau \& Horvat, 1999) for Black males, by either opening or closing doors to educational advancement and social mobility.

These examples must be understood within the context of the prevailing research literature, which reveals that Black male youth are often denied meaningful educational opportunities, where they are tracked out of upper ability or college preparatory programs and into remedial, vocational or even special education programs (Catsambis, 1994; National Research Council, 2002; Darling-Hammond, 1994; Ford, Grantham, \& Whiting, 2008; Grantham, 2004a, 2004b; Harry \& Klingner, 2006; Hrabowski III, Maton, \& Greif, 1998; Linnehan, Weer, \& Stonely, 2011; Oakes, 2005). While majoritarian discourses favor cultural impediments to explain academic placement,(Herrnstein \& Murray, 1994; Mitchell, 2013), CRT exposes micro-level structural factors, such as academic gatekeeping that tend to disproportionally impact Black males and perpetuate racial subordination.

However, the responses by parents and school personnel to these unjust practices provide insight into how schools might be transformed for the benefit of Black males. For instance, in the first example presented, the parents demonstrated agency through the presentation of their own counter-stories. By contesting dominant assumptions of their sons and activating their own cultural capital by making their concerns known to the schools, the parents were able to influence school process by advocating for the hiring of a more culturally aware counseling staff. Similarly, there is hope in how educators, and particularly counselors, are starting to be trained in culturally relevant and socially just 
practices (Holcomb-McCoy \& Day-Vines, 2004; Sue, Arredondo, \& McDavis, 1992). Thus the school's hiring of counselors who were trained to work with culturally diverse populations presents the type of opportunities toward systemic change made possible through education preparation programs.

School administrators. A similar hope then, must also be identified for school administrators who are no less likely to adopt deficit views of their student populations (White-Smith, 2012a, 2012b). However, as school leaders, their beliefs about Black males and the corresponding environmental cues within the school campus become a meaningful part of the hidden curriculum, where Black youth come to learn what they can expect of the future. In some cases, the environmental cues regarding Black male deviancy are blatant (e.g. increased police presence on campus) as school administrators implement practices that unjustly target Black males.

In a particular study of Black middle-class males (Allen, 2013) the principal of a racially diverse school in a middle-class suburb invited local police and sheriff authorities to a monthly parent meeting specifically for Black parents. The purpose of inviting law enforcement was to inform the parents of how to address gang violence, but to the parents it appeared to be a "witch-hunt" of Black male students and a way to further incarcerate more Black bodies. Mr. Mensah, a father at this meeting, best reflects this tension:

I went to a meeting. They were talking about gang violence... and I heard the whole spiel, Glenpark police, Glenpark sheriff, the county sheriff, detectives, the whole nine yards and they're telling all the parents what to look for. The hats and if there are tattoos or the cuts in the eyebrows, and they're telling all these things to look out for and I'm sitting there and I just 
couldn't take in no more and I had to really calm myself because I was going to be yelling and my voice was shaking and I said, 'You know? I've sat here for 45 minutes to an hour and I listened to you and all you police and detectives say what to look for in the kids...This witch-hunt, what you're doing, is kids. These are kids that live in $\$ 600,000$ homes, million [dollar] homes. But because this is the fad to dress like this, now you're telling the parents to look at their kids as gang members and not as kids anymore, that can be changed or influenced. You're saying this is what you look for and when you find it call us so we can take your kids away. And I said because all you've done is you've told me to hold on to my kids that much closer because what you're trying to do is arrest them and get rid of them' (p. 180).

Mr. Mensah's counter-story points to a unique intersection of race, class, gender, and youth culture for the Black males at this school (Allen, 2013). Even though these students attended a middle-class suburban school and largely came from middle-class homes, they and presumably their parents were still subject to racial profiling by law enforcement, further highlighting the endemic nature of race and racism.

While the invitation of law enforcement to a parent meeting specifically for Black parents may have been perceived by school administrators as politically neutral, it was clear to Mr. Mensah that administrators supported a campus environment of distrust and surveillance. The presence of law enforcement on urban and racially diverse school campuses continues to grow, as police forces are 
called upon to be community liaisons or to maintain order within the school (Price, 2009; Reaves, 2011). The increasing presence of law enforcement also places the Black male body under excessive surveillance and regulation (Foucault, 1979). Where the school once solely handled infractions such as dress code violations or class disruptions, these events are now subject to police observation, intervention, and criminalization (Losen \& Martinez, 2013; Nolan \& Willis, 2011; Theriot, 2009). And since Black boys are disproportionally disciplined (often for minor or subjective infractions), police presence on campus only subjects Black male students to increased encounters with law enforcement policies and practices, directly placing Black boys into the criminal justice system (Noguera, 2003; Price, 2009; Theriot, 2009).

This incident, along with the others presented, are just a few examples of the many ways Black males encounter the school-to-prison pipeline (Ayers, Dohrn, \& Ayers, 2001; A. Ferguson, 2000; Gibson, 2002; Harry \& Klingner, 2006; Noguera, 2003). However, the examples presented also point to particular settings from which we can endeavor to dismantle this pipeline. Because the teachers, counselors, and administrators largely come through education programs, we argue this is a location where school barriers to Black males can be addressed. Specifically, undergraduate education programs can prepare educators with the competencies and dispositions needed to work with culturally diverse populations, particularly Black males (Gay, 2002; Howard, 2001; LadsonBillings, 1995). In the next section we provide recommendations for practice using our own approach to preparing future educators. 


\section{Integrated Educational Studies: Re-envisioning teacher and community education}

Dismantling the school-to-prison pipeline for Black males is a multifaceted problem requiring a comprehensive approach. As part of a larger ecology of the Black male experience, we understand that schools are one of many institutions and cultural formations that systematically marginalize Black males.. For this reason, we believe that educator preparation programs have a particular responsibility within this ecology and can be an important catalyst for change. This may be particularly true, since many of the individuals involved at the institutional level with Black males matriculate from college and universities. Our recommendations draw upon the work currently being conducted in our own educator preparation program as a model. We do not purport that the model we present is the definitive answer to addressing the school-to-prison pipeline, but instead should be seen as one of many approaches and environments from which solutions can be discovered. In our case, we focus on how an undergraduate education program can begin to equip future educators with the professional skills, cultural competencies, and dispositions needed to transform schools from prison pipelines to institutions of opportunity.

Like many colleges and schools of education, our student population is largely White, middle class and female, with intentions of working in traditional or nontraditional educational settings. Thus, these are individuals who may profoundly shape the social trajectory of Black male students through their work as educators in and around schools. When developing the program, we recognized an opportunity to change the way we as teacher educators defined education and consequently, the way we prepared educators. Through our work with parent groups, non-profit organizations, afterschool 
programs, social service agencies, and businesses, we began to see the interconnectedness between all these locations to schools, family, and children. If we are to truly impact the lives of children, we needed to broaden our sphere of influence.

We re-envisioned and undergraduate education program that would develop informed decision-makers and change agents both in schools and in the society at large. The new major, Integrated Educational Studies (IES), prepares students for careers in the field of education, broadly defined to include all aspects of traditional schooling, as well as education in community settings. Graduates of the program are equipped to pursue careers in traditional education settings, such as K-12 teaching, special education and disability services, and school counseling and psychology. They are also equipped to pursue other educational endeavors related to non-profit organizations, social entrepreneurship, business, and health care fields among other community education settings.

The curriculum combines challenging coursework with guided experiences in school or other community settings. The major is organized to address five key roles that educators need to acquire:

1) Leader and Change Agent - The ability to discern the needs of others and use relevant information, skills, and abilities. Incorporates values to problem solve and promote development in guiding and supporting others.

2) Ethically Responsible Decision-Maker - Engage in personal transformation in order to act as a catalyst for social transformation

3) Learner and Scholar - Exhibit the methods, discipline, evidence, attainment and dissemination of knowledge. 
4) Advocate for Inclusive and Supportive Communities - The ability to consider multiple perspectives and demonstrate support or make informed recommendations publicly; and

5) Facilitator and Collaborator - Explore opportunities for accepting assistance and being of service.

Assessments for acquisition of these roles are embedded into all core courses, coupled with a critically assessed culminating portfolio.

Upon admission into the program, students are immersed in coursework and field experiences that challenge their understanding of privilege, difference, culture, and social inequality. Students are constantly asked to reflect on their own identity, their personal biases, and their role in the maintenance or disruption of inequality. The embedded nature of this content into almost every course they take essentially makes it very difficult for a student to avoid this type of knowledge.

For example, during the first year of the program, students take a class titled "The social construction of difference," which explores the "social construction of race, class, gender, sexuality, and disability," and "how systems of stratification are formed, perpetuated, and interconnected through language and social institutions, such as schools, public policy, and media" (Catalog, 2012). In addition, students are expected to consider how they as individuals may play a transformative role in the construction of difference. The content of this course lays the groundwork for inquiry through the rest of the program as concepts and ideas are expanded upon in subsequent courses.

Moreover, students from majors across campus are able to access our courses. It's encouraging that our courses dealing specifically with critical issues regarding race, class, 
gender and other identities are overwhelmingly enrolled with film, business, and political science majors in addition to the education majors. It is our intent that our program goes beyond simply preparing educators but also equipping those who may go on to work in media, policy, law, and business with the cultural competencies needed to work with or represent Black male youth.

Students actually enrolled in the IES major are also exposed to diverse field experiences where theory and practice meet. Working alongside professionals in culturally diverse public schools and community settings, students not only learn valuable professional skills, but they are also exposed to the cultural mores of the local communities. For example, students conduct field experiences in culturally diverse K-12 school settings including a university affiliated dual language school. In the different school settings, we ask our students to collect observation data on how school policies and practices might impact students of color, including how Black boys might be denied opportunities to learn or get excessively reprimanded. Many students work with a local urban community bookstore that provides a series of community education and arts based programs. In doing so, students learn how schools and communities can support each other in providing culturally relevant educational experiences. Other students conduct fieldwork with grass roots community engagement parent groups, or work with nonprofits that provide intra-group relations, community conflict resolution and police force cultural competence training.

When students conduct fieldwork in these settings, it also allows faculty to problematize the deficit views of culture the students may adopt or deduce from their observations. While drawing attention to the structural influences on culture, students 
also learn the value of identifying cultural assets and how community cultural wealth (Yosso, 2005) may be employed in their own teaching and leadership practices.

Furthermore, considering the counter-stories presented in this paper about Black male schooling, the fieldwork experiences of IES majors, and the institutional actors they work with in these settings (e.g. teachers, parents, law enforcement, etc.) might present opportunities for social justice on behalf of Black males. In other words, we hope to prepare race conscious and social justice minded individuals who will be motivated to work collectively through their roles as institutional agents in dismantling the prison pipeline for Black males.

\section{Conclusion}

Since most educators will matriculate through education preparation programs, we've focused on these programs as potential sites of counter-hegemonic activity, where institutional agents can gain the capacity to become "powerbrokers" (Brayboy, 2005), acting intentionally in ways that disrupt stratifying school processes. In addition to developing a skilled workforce and a knowledgeable citizenry, schools are ideal sites for social transformation Thus, schools play an important role in the collective process of improving the life trajectories of Black males., Our focus on education programs must be understood within the larger ecology of the Black male experience. Schools are one of many institutions and cultural formations that interact and inform each other in ways that perpetuate inequality for Black males. Metaphorically speaking, if schools represent the scaffold for the pipeline, then communities, law enforcement, media, and public policy provide the bolts and steel that strengthen and entrench it. It will take a collective effort 
to dismantle a pipeline that we as a society have collectively created, but schools, and the institutional brokers working within them, are positioned to be the catalyst for this change. 


\section{References}

Allen, Q. (2010a). Black middle-class males, their parents, and their teachers: A process of social reproduction through education. Ph.D. Dissertation, Arizona State University, Tempe. Retrieved from http://proquest.umi.com/pqdlink?did=2037992971\&Fmt=7\&clientId=79356\&RQ $\mathrm{T}=309 \&$ VName $=\mathrm{PQD}$

Allen, Q. (2010b). Racial microaggressions: The schooling experiences of black middleclass males in arizona's secondary schools. Journal of African American Males in Education, 1(2), 125-143.

Allen, Q. (2013). "They think minority means lesser than": Black middle-class sons and fathers resisting microaggressions in the school. Urban Education, 48(2), 171197.

Anyon, J. (1981). Social class and school knowledge. Curriculum Inquiry, 11(1), 3-42.

Aud, S., Fox, M. A., \& Kewal Ramani, A. (2010). Status and trends in the education of racial and ethnic minorities. Washington, DC: U.S. Departmen of Education, National Center for Education Statistics.

Ayers, W., Dohrn, B., \& Ayers, R. (Eds.). (2001). Zero tolerance: Resisting the drive for punishment in our schools. New York: The New Press.

Banks, W. M. (1978). Models of culture and school counselors: The predicament of black youth. Anthropology \& Education Quarterly, 9(2), 137-147.

Barrett, J. R., \& Roediger, D. (2003). How white people became white. In J. F. Perea, R. Delgado, A. P. Harris \& S. M. Wildman (Eds.), Race and races: Cases and resources for a diverse america (pp. 445 - 450). St. Paul, Minn: West Group.

Beard, K. S., \& Brown, K. M. (2008). Trusting schools to meet the academic needs of african-american students? Suburban mothers' perspectives. International Journal of Qualitative Studies in Education, 21(5), 471-485.

Bell, D. (1992). Faces at the bottom of the well: The permanence of racism. New York: Basic Books.

Bowles, S., \& Gintis, H. (2002). Schooling in capitalist america revisited. Sociology of Education, 75(2), 1 - 18.

Brayboy, B. M. J. (2005). Transformational resistance and social justice: American indians in ivy leagure universities. Anthropology and Education Quarterly, 36(3), 193-211. 
Catalog, U. (2012). 2012-2013 undergraduate catalog. In C. University (Ed.). Orange, CA.

Catsambis, S. (1994). The path to math: Gender and racial-ethnic differences in mathematics participation from middle school to high school. Sociology of Education, 67(3), 199 - 216.

Causey, V. E., Thomas, C. D., \& J. Armento, B. (2000). Cultural diversity is basically a foreign term to me: The challenges of diversity for preservice teacher education. Teaching and Teacher Education, 16(1), 33-45. doi: http://dx.doi.org/10.1016/S0742-051X(99)00039-6

Constantine, M. G., \& Gushue, G. V. (2003). School counselors' ethnic tolerance attitudes and racism attitudes as predictors of thier multicultural case conceptualization of an immigrant student. Journal of Counseling and Development, 81(2), 185-190.

Cooper, C. W. (2003). The detrimental impact of teacher bias: Lessons learned from the standpoint of african american mothers. Teacher Education Quarterly, 30(2), 101116.

Coopersmith, J. (2009). Characteristics of public, private, and bureau of indian education elementary and secondary school teachers in the united states: Results from the 2007-08 schools and staffing survey (nces 2009-324). Washington, DC. : U.S. Department of Education, National Center for Education Statistics, Institute of Education Sciences.

Council. (2009). Accreditation procedures manual and application. Alexandria, VA: Council for the Accreditation of Counseling and Related Educational Programs.

Council, N. R. (2002). Minority students in special and gifted education. In M. S. Donovan \& C. T. Cross (Eds.), Committee on Minority Representation in Special Education, Division of Behavioral and Social Sciences and Education. Washington, DC: National Academy Press.

Crenshaw, K. (1993). Demarginalizing the intersection of race and sex: A black feminist critique of antidiscrimination doctrine, feminist theory, and antiracist politics. In D. K. Weisberg (Ed.), Feminist legal theory (pp. p. 383 - 395). Philadelphia: Temple University Press.

Crenshaw, K., Gotanda, N., Peller, G., \& Thomas, K. (Eds.). (1995). Critical race theory: The key writings that formed the movement. New York: The New Press.

Darling-Hammond, L. (1994). Performance-based assessment and educational equity. Harvard Educational Review, 64(1), 5 - 30.

Davis, J. E. (2003). Early schooling and academic achievement of african american males. Urban Education, 38(5), 515 - 537. 
Delgado, R. (1991). Brewer's plea: Critical thoughts on common cause. Vanderbilt Law Review, 44(11), 1-13.

Delgado, R. (1995). Legal storytelling: Storytelling for oppositionists and others: A plea for narrative. In R. Delgado (Ed.), Critical race theory: The cutting edge (pp. 64 74). Philadelphia: Temple University Press.

Delgado, R., \& Stefancic, J. (2001). Critical race theory: An introduction. New York: New York University Press.

Delpit, L. (1995). Other people's children: Cultural conflicts in the classroom. New York New Press.

Dixson, A. D., \& Rousseau, C. K. (2006). Are we still not saved: Critical race theory in education ten yeas later. In A. D. Dixson \& C. K. Rousseau (Eds.), Critical race theory in education: All god's children got a song (pp. 31-54). New York: Routledge.

Erickson, F. (1975). Gatekeeping and the melting pot: Interaction in counseling encounters. Harvard Educational Review, 45(1), 44-70.

Fanon, F. (1967). Black skin, white masks. New York: Grove Press.

Fenning, P., \& Rose, J. (2007). Overrepresentation of african american students in exclusionary discipline: The role of school policy. Urban Education, 42(6), 536559.

Ferguson, A. (2000). Bad boys: Public schools in the making of black masculinity. Ann Arbor: The University of Michigan Press.

Ferguson, R. (2005). Teachers' perceptions and expectations and the black-white test score gap. In O. S. Fashola (Ed.), Educating african american males: Voices from the field (pp. 79 - 128). Thousand Oaks, CA: Corwin Press.

Fernandez, L. (2002). Telling stories about school: Using critical race and latino critical theories to document latina/latino education and resistance. Qualitative Inquiry, $8(1), 45-65$.

Ford, D. Y. (1998). The underrepresentation of minority students in gifted education: Problems and promises in recruitment and retention. The Journal of Special Education, 32(1), 4-14.

Ford, D. Y., Grantham, T. C., \& Whiting, G. W. (2008). Culturally and linguistically diverse students in gifted education: Recruitment and retention issues. Exceptional Children, 74(3), 289-306.

Foucault, M. (1979). Discipline and punish (A. Sheridan, Trans.). New York: Vintage. 
Gay, G. (2002). Preparing for culturally responsive teaching. Journal of Teacher Education, 53(2), 106-116.

Gibson, C. (2002). Being real: The student-teacher relationship and african-american male delinquency. New York: LFB Scholarly Publishing.

Grantham, T. C. (2004a). Multicultural mentoring to increase black male representation in gifted programs. Gifted Child Quarterly, 48(3), 232 - 245.

Grantham, T. C. (2004b). Rocky jones: Case study of a high-achieving black male's motivation to participate in gifted classes. Roeper Review, 26(4), 208 - 215.

Gregory, A., Skiba, R., \& Noguera, P. (2010). The achievement gap and the discipline gap: Two sides of the same coin? Educational Researcher, 39(1), 59-68.

Gregory, A., \& Weinstein, R. S. (2008). The discipline gap and african americans: Defiance or cooperation in the high school classroom. Journal of School Psychology, 46(4), 455-475.

Guerino, P., Harrison, P. M., \& Sabol, W. (2011). Prisoners in 2010. Washington, DC: Bureau of Justice Statistics.

Harper, S. R., \& Davis III, C. H. F. (2012). They (don't) care about education: A counternarrative on black male students' responses to inequitable schooling. Educational Foundations, 26(1), 103-120.

Harris, C. I. (1993). Whiteness as property. Harvard Law Review, 106(8), 1707-1791.

Harry, B., \& Klingner, J. (2006). Why are so many minority students in special education? Understanding race and disability in schools. New York: Teachers College Press.

Herrnstein, R. J., \& Murray, C. (1994). The bell curve: Intelligence and class structure in american life. New York, NY: Free Press.

Hoffman, K., Llagas, C., \& Snyder, T. D. (2003). Status and trends in the education of blacks. Washington, D.C.: US Department of Education, National Center for Educational Statistics.

Holcomb-McCoy, C., \& Day-Vines, N. L. (2004). Exploring school counselor multicultural competence: A multidimensional concept. Measurement and Evaluation in Counseling and Development, 37(3).

hooks, b. (1995). Transformative pedagogy and multiculturalism. In T. Perry \& J. W. Fraser (Eds.), Freedom's plow: Teaching in the multicultural classroom (pp. 9198). New York, NY: Routledge.

hooks, b. (2003). We real cool: Black men and masculinity. New York: Routledge. 
Horkheimer, M. (1972). Critical theory: Selected essays (M. J. O. C. a. others, Trans.). New York: Herder and Herder.

Howard, T. C. (2001). Powerful pedagogy for african-american students: A case of four teachers. Urban Education, 36(2), 179 - 202.

Howard, T. C., \& Reynolds, R. (2008). Examining parent involvement in reversing the underachievement of african american students in middle-class schools.

Educational Foundations, 22(1-2), 79-98.

Hrabowski III, F. A., Maton, K. I., \& Greif, G. L. (1998). Beating the odds: Raising academically successful african american males. New York: Oxford University Press.

Ladson-Billings, G. (1995). Toward a theory of culturally relevant pedagogy. American Educational Research Journal, 32(3), 465 - 491.

Ladson-Billings, G. (1996). Silences as weapons: Challenges of a black professor teaching white students. Theory into Practice, 35(2), 79-85.

Ladson-Billings, G., \& Tate IV, W. F. (1995). Toward a critical race theory of education. Teachers College Record, 97(1), 47 - 68.

Lareau, A., \& Horvat, E. M. (1999). Moments of social inclusion and exclusion: Race, class, and cultural capital in family-school relationships. Sociology of Education, 72(1), 37-53.

Linnehan, F., Weer, C. H., \& Stonely, P. (2011). High school guidance counselor recommendations: The role of student race, socioeconomic status, and academic performance. Journal of Applied Social Psychology, 41(3), 536-558.

Losen, D. J. (2011). Discipline policies, successful schools, and racial justice. Retrieved from http://nepc.colorado.edu/publication/disciplinepolicieshttp://nepc.colorado.edu/publication/discipline-policies

Losen, D. J., \& Martinez, T. E. (2013). Out of school \& off track: The overuse of suspensions in american middle and high schools The Center for Civil Rights Remedies.

Lynn, M., Bacon, J. N., Totten, T. L., Bridges, T. L., \& Jennings, M. E. (2010). Examining teachers' beliefs about african american male students in a lowperforming high school in an african american school district. Teachers College Record, 112(1), 289-330.

Matsuda, M. J., Lawrence III, C. R., Delgado, R., \& Crenshaw, K. W. (Eds.). (1993). Words that wound: Critical race theory, assaultive speech, and the first amendment. Boulder, CO: Westview Press. 
Melnick, S. L., \& Zeichner, K. (1995). Teacher education for cultural diversity: Enhancing the capacity of teacher education institutions to address diversity issues.: National Center for Research on Teacher Learning.

Mickelson, R. A. (2001). Subverting swann: First and second generation segregation in the charlotte-mecklenburg school system. American Educational Research Journal, 38(2), 215-252.

Milner IV, H. R. (2005). Stability and change in u.S. Prospective teachers' beliefs and decisions about diversity and learning to teach. Teaching and Teacher Education, 21(7), 767-786. doi: 10.1016/j.tate.2005.05.010

Milner IV, H. R. (2008). Critical race theory and interest convergence as analytic tools in teacher education policies and practices. Journal of Teacher Education, 59(4), 332-346.

Mitchell, K. (2013). Race, difference, meritocracy, and english: Majoritarian stories in the education of secondary multilingual learners. RACE ETHNICITY AND EDUCATION, 16(3), 339-364.

Monroe, C. R. (2005). Why are "bad boys" always black? Causes of disproportionality in school discipline and recommendations for change. The Clearing House, 79(1), 45-50.

Nicholson-Crotty, S., Birchmeier, Z., \& Valentine, D. (2009). Exploring the impact of school discipline on racial disproportion in the juvenile justice system. [Article]. Social Science Quarterly (Wiley-Blackwell), 90(4), 1003-1018. doi: 10.1111/j.1540-6237.2009.00674.x

Noguera, P. A. (2003). Schools, prisons, and social implications of punishment: Rethinking disciplinary practices. Theory Into Practice, 42(4), 341 - 350.

Nolan, K., \& Willis, P. (2011) Police in the hallways: Discipline in an urban high school. Minneapolis; London: University of Minnesota Press.

Oakes, J. (2005). Keeping track: How schools structure inequality. New Haven, CT: Yale University Press.

Oliver, M. L., \& Shapiro, T. M. (2010). Race, wealth, and equality. In M. Adams (Ed.), Readings for diversity and social justice (2 ed., pp. 162-169). New York, NY: Routledge.

Orfield, G., \& Lee, C. (2007a). Historic reversals, accelerating resegregation, and the need for new integration strategies. Los Angeles, CA: The Civil Rights Project.

Orfield, G., \& Lee, C. (2007b). Historic reversals, accelerating resegregation, and the need for new intergration strategies: UCLA Civil Rights Project. 
Pettit, B., \& Western, B. (2004). Mass imprisonment and the life course: Race and class inequality in u.S. Incarceration. American Sociological Review, 69(2), 151-169. doi: $10.1177 / 000312240406900201$

Price, P. (2009). When is a police officer an officer of the law?: The status of police officers in schools, 541.

Raible, J., \& Irizarry, J. G. (2010). Redirecting the teacher's gaze: Teacher education, youth surveillance and the school-to-prison pipeline. Teaching and Teacher Education, 26(5), 1196-1203.

Rashid, H. M. (2009). From brilliant baby to child placed at risk: The perilous path of african american boys in early childhood education, 347.

Reaves, B. (2011). Census of state and local law enforcement agencies, 2008. Washington, DC: U.S. Department of Justice Retrieved from http://www.bjs.gov/index.cfm?ty=pbdetail\&iid=2216.

Sampson, R. J. (1987). Urban black violence: The effect of male joblessness and family disruption, 348.

Skiba, R. (2001). When is disproportionality discrimination? The overrepresentation of black students in school suspension. In W. Ayers, B. Dohrn \& R. Ayers (Eds.), Zeo tolerance: Resisting the drive for punishment in our schools (pp. 176 - 187). New York: New Press.

Solorzano, D. G. (1997). Images and words that wound: Critical race theory, racial stereotyping, and teacher education. Teacher Education Quarterly, 24(3), 5 - 19.

Solorzano, D. G. (1998). Critical race theory, race and gender microaggressions, and the experience of chicana and chicano scholars. International Journal of Qualitative Studies in Education, 11(1), 121 - 136.

Solorzano, D. G., \& Bernal, D. D. (2001). Examining transformational resistance through a critical race and latcrit theory framework: Chicana and chicano students in an urban context. Urban Education, 36(3), 308-342.

Solorzano, D. G., \& Yosso, T. J. (2009). Critical race methodology: Counter-storytelling as an analytical framework for educational research. In E. Taylor, D. Gillborn \& G. Ladson-Billings (Eds.), Foundations of critical race theory in education (pp. 131-147). New York, NY: Routledge.

Sue, D. W., Arredondo, P., \& McDavis, R. J. (1992). Multicultural counseling competencies and standards: A call to the profession. Journal of Counseling and Development, 70(4), 477-486. 
Sum, A., Khatiwada, I., \& McLaughlin, J. (2009). The consequences of dropping out of high school: Joblessness and jailing for high school dropouts and the high cost for taxpayers: Center for Labor Market Studies Publications.

Swain, A., \& Noblit, G. (2011). Education in a punitive society: An introduction. [Article]. Urban Review, 43(4), 465-475. doi: 10.1007/s11256-011-0186-X

Tab, E. D. (2007). Characteristics of schools, districts, teachers, principals, and school libraries in the united states: 2003-04. Washington, DC: National Center for Education Statistics

Theriot, M. T. (2009). School resource officers and the criminalization of student behavior, 280 .

U.S. Department of Labor. (2013). Employment situation. Washington, DC: Bureau of Labor Statistics Retrieved from http://www.bls.gov/bls/newsrels.htm - OEUS.

van den Bergh, L., Denessen, E., Hornstra, L., Voeten, M., \& Holland, R. W. (2010). The implicit prejudiced attitudes of teachers: Relations to teacher expectations and the ethnic achievement gap. American Educational Research Journal, 47(2), 497527.

Vavrus, M. J. (2002). Transforming the multicultural education of teachers. New York, NY: Teachers College Press.

Vincent, C., Rollock, N., Ball, S., \& Gillborn, D. (2012). The educational strategies of the black middle classes. In M. Richter \& S. Andresen (Eds.), The politicization of parenthood: Shifting private and public responsibilities in education and child rearing (Vol. 5, pp. 139-152). London and New York: Springer.

Wald, J., \& Losen, D. J. (2003). Defining and redirecting a school-to-prison pipeline. [Article]. New Directions for Youth Development, 2003(99), 9-15.

Watson, D. (2011). "Urban, but not too urban": Unpacking teachers' desires to teach urban students. Journal of Teacher Education, 62(1), 23-34.

White-Smith, K. A. (2012a). Beyond instructional leadership: The lived experiences of principals in successful urban schools. Journal of School Leadership, 22(1), 6-25.

White-Smith, K. A. (2012b). The struggle for identity in a teacher community. In E. R. Hollins (Ed.), Learning to teach in urban schools: The transition from preparation to practice / etta r. Hollins (pp. 63-82). New York, NY: Routledge.

Wiggins, R. A., Follo, E. J., \& Eberly, M. B. (2007). The impact of a field immersion program on pre-service teachers' attitudes toward teaching in culturally diverse classrooms. Teaching and Teacher Education, 23(5), 653-663. doi: http://dx.doi.org/10.1016/j.tate.2007.02.007 
Yancy, G. (2005). Whiteness and the return of the black body. The Journal of Speculative Philosophy, 19(4), 215-241.

Yosso, T. (2006). Critical race counterstories along the chicana/chicano educational pipeline. New York, NY: Routledge. 